\title{
VALIDACIÓN DE PCR PARA EL DIAGNÓSTICO DE HEPATITIS B
}

\author{
Autores: \\ Víctor Espín ${ }^{1}$ \\ Alejandra Espín ${ }^{2}$ \\ Camilo Zurita \\ Vinicio Navas ${ }^{1}$
}





\section{Resumen}

La presente investigación busca implementar la técnica reacción en cadena de la polimerasa (PCR) simple para identificar virus de hepatitis B (VHB). Gracias a su alta sensibilidad y especificidad, la PCR puede amplificar una región específica del genoma del virus cientos de veces a partir de muy poco ADN inicial y, de esta forma, visualizarlo por medio de bandas electroforéticas en geles de agarosa. Se tomaron muestras sanguíneas de 26 pacientes y 9 voluntarios en la Ciudad de Quito. En todas las muestras de estos pacientes, además de las pruebas de PCR se realizaron también pruebas de antígeno de superficie y antígeno de envoltura del virus por ELISA como medio de diagnóstico de hepatitis B.

Durante el desarrollo de la investigación se evidenció que de los 26 pacientes, el 100 \% resultaron positivos para hepatitis B, el 100 \% resultó positivo a la prueba de ELISA para antígeno de superficie, el 69\% resultó positivo para antígeno e (HBeAg), el 100\% resultó positivo en PCR, presentando una banda de $447 \mathrm{pb}$ en gel de agarosa al $2 \%$, valor predictivo positivo 1, valor predictivo negativo 1 , sensibilidad $100 \%$ y especificidad $100 \%$.

En base a las observaciones realizadas y las pruebas desarrolladas se evidenció que el uso del PCR para el diagnóstico de hepatitis B es una alternativa válida en casos específicos de pacientes en quienes no se puede descartar por completo la presencia del virus por otro tipo de pruebas como el ELISA.

Palabras clave: Reacción de Cadena de la Polimerasa (PCR), Antígeno de Superficie (HBsAg), Antígeno de envoltura (HBeAg), Virus de Hepatitis B (VHB).

\section{Abstract}

At this study, we attempted to use simple polymerase chain reaction (PCR) to detect hepatitis B virus (HBV) in human blood samples. PCR is a sensitive and specific test for amplifying a sequence of HBV DNA hundreds of times from a small quantity of initial DNA. This test can allow us to visualize DNA in a $2 \%$ agarose gel electrophoresis. Samples were collected from 26 patients infected with HBV confirmed by ELISA test to detect antibodies to hepatitis B surface antigen (HBsAg) and e-antigen (HBeAg) and, from 9 volunteers. Results: among 26 patients $\mathrm{HBV}+, 100 \%$ patients were considered positive for surface antigen (HBsAg), 69\% were considered positive for e-antigen (HBeAg), and 100\% were positive for PCR, showing 447bp bands in agarose gel (2\%), Sensibility $100 \%$, Specificity $100 \%$.

Conclusion: PCR is a very good alternative to be used in very specific cases such as patients in whom there is uncertainty about the presence of the hepatits virus after doing others test like ELISA.

Key words: Polymerase Chain Reaction (PCR), Antigen Surface (HBsAg), e-Antigen (HBeAg), and Hepatitis B Virus (HBV).

Recibido: Mayo 2012

Aprobado: Julio 2012 


\section{Introducción}

De acuerdo a cifras proporcionadas por el Ministerio de Salud Pública del Ecuador (1) 3.658 personas fueron infectadas por el virus hepatitis B desde el año 1996 al 2005. Dentro de este grupo de pacientes hubo algunos que presentaron infecciones de tipo asintomático (2).

La identificación inicial del virus de hepatitis $B$ se lo hace básicamente por medio de pruebas serológicas de inmuno ensayo como ELISA. El problema de las pruebas inmunológicas es que en ellas pueden incidir una serie de factores (estado inmunológico general del paciente; cantidad de patógeno existente; reacciones cruzadas, etc.) que pueden afectar la sensibilidad y la especificidad de las mismas. La biología molecular ofrece una técnica como la reacción en cadena de la polimerasa (PCR) que brinda una alta sensibilidad y especificidad para detectar el patógeno, incluso en bajas concentraciones y sin importar el estado inmune del paciente. Estas técnicas han venido a complementar la utilidad de otras pruebas como ELISA, permitiéndonos realizar un mejor diagnóstico y seguimiento de esta infección y de la respuesta que presentan los pacientes a los tratamientos con antivirales (4).

El objetivo del estudio fue implementar la utilización del PCR como método de diagnóstico de la hepatitis B en el Ecuador introduciendo una prueba de alta sensibilidad y especificidad $\sin$ la utilización de equipos sofisticados; así como, estandarizar un protocolo que sea de fácil utilización en nuestro medio y de bajo costo. De especial interés ha sido diagnosticar esta infección en pacientes asintomáticos quienes pueden mantener el HBsAg o anti$\mathrm{HBeAg}$ sin actividad necroinflamatoria aparente; aproximadamente del 1 al $2 \%$ de estos pacientes pueden dejar su estado de portador y desarrollar daño hepático (2).

Esta infección oculta causada por el Virus Hepatitis B constituye un estado en el cual no existe la presencia de marcadores serológicos positivos; sin embargo, suele encontrarse DNA viral en suero o más frecuentemente en células del hígado en estados de inmunodeficiencia, como en los pacientes con transplantes (2).

\section{Hipótesis}

¿Es posible realizar una reacción en cadena de polimerasa $(P C R)$ de bajo costo para diagnosticar hepatitis B?

\section{Materiales y Métodos}

\section{Pacientes}

La población en la cual se realizó el estudio fue de 35 pacientes; 26 con diagnóstico de hepatitis B mediante pruebas de HBsAg o HBeAg. El grupo A consistió de 8 pacientes con diagnóstico de hepatitis crónica cuyo suero contenía antígeno de superficie (HBsAg) en pruebas de Elisa realizadas a los mismos y HBeAg (-). El grupo B lo constituyeron 18 pacientes con diagnóstico de hepatitis $\mathrm{B}$ cuyo suero contenía antígeno de superficie para HBV (HBsAg) y antígeno HBV e (HBeAg) de los cuales 17 eran sintomáticos y un paciente era asintomático, ya que no presentaba sintomatología característica de la enfermedad y pruebas hepáticas como TCO, TGP y bilirrubinas normales. El grupo C lo constituyó un grupo de 6 voluntarios jóvenes y un adulto no vacunados para hepatitis B y sin diagnóstico de hepatitis B. El grupo D lo constituyeron 2 voluntarios vacunados para hepatitis B. La toma de la muestra se realizó previo consentimiento informado de los pacientes en tubos sin anticoagulante con la obtención inmediata del suero.

Los pacientes eran procedentes de diferentes sitios: La Cruz Roja Ecuatoriana; Hospital Carlos Andrade Marín; Baxter Ecuador (Centro de Hemodiálisis); Laboratorios Zurita y Zurita y Hospital de Niños Baca Ortiz. Todas las muestras de ADN utilizadas en este estudio fueron destruidas y desechadas después de la amplificación. 


\begin{tabular}{|l|l|l|l|}
\hline $\begin{array}{l}\text { NOMENCLATURA } \\
\text { DEL PACIENTE }\end{array}$ & $\left.\mathrm{(} \mathrm{N}^{\circ}\right)$ & PROCEDENCIA & ANTIGENO \\
\hline A & 8 & Baxter. Unidad de diálisis & HBsAg +, HBeAg- \\
\hline B & 18 & $\begin{array}{l}\text { Baxter, CRUZ ROJA } \\
\text { (donantes), HCAM } \\
\text { (donantes })\end{array}$ & HBsAg + Y HBeAg+ \\
\hline C & 7 & Voluntarios & $\begin{array}{l}\text { NO DG. HEPATITIS B- } \\
\text { NO VACUNADOS }\end{array}$ \\
\hline D & 2 & Voluntarios & VACUNADOS HB \\
\hline
\end{tabular}

Tabla 1. Distribución de muestras según su centro de procedencia

\section{Pruebas de Elisa}

El principio de detección de HBsAg y HBeAg adopta una forma de "principio de sánduche" (anticuerpo-antígeno-anticuerpo), cuando son incubados con la muestra que contiene el HBsAg. El antiHBs adherido a los pozos y el anti-HBs conjugado son incubados con la muestra que contienen el $\mathrm{HBsAg}$, formando en los pozos un complejo. Después del lavado la actividad de la peroxidasa en los pozos refleja la presencia de HBsAg en la muestra (9).

La muestras que pueden ser suero o plasma, deben ser almacenadas a $2-8^{\circ} \mathrm{C}$ si el estudio se realiza en un período corto o pueden ser congeladas a $-20^{\circ} \mathrm{Cu}-80^{\circ} \mathrm{C}$, hasta la realización del estudio. No es recomendable descongelar la muestra varias veces (10).

\section{Procedimiento}

\section{Elisa}

Para este proceso se realizaron los siguientes pasos:

a) Antes de iniciar el procedimiento se llevaron todos los reactivos y muestras a temperatura ambiente $\left(20-30^{\circ} \mathrm{C}\right)$.

b) Se ajustó el incubador a baño maría a $37^{\circ} \mathrm{C}$.

c) Reservar dos pozos como controles. Añadir $50 u l$ de cada control o muestra a los apropiados pozos de reacción. Añadir 5oul de solución de anti-HBs-peroxidasa a cada pozo, excepto los dos controles.

d) Mezclar suavemente la placa.

e) Remover el adhesivo protector y colocarlo sobre los pozos. f) Incubar la reacción a $371^{\circ} \mathrm{C}$ por 80 minutos. Retirar el adhesivo y lavar los pozos.

g) Añadir sucesivamente $50 u$ de solución de TMB sustrato A, $50 u l$ de solución TMB sustrato $B$, en cada pozo incluyendo los dos controles. Mezclar suavemente. Cubrir los pozos con el adhesivo e incubar por 30 minutos a temperatura ambiente. Parar la reacción colocar 10oul de $2 \mathrm{~N} \mathrm{H}_{2} \mathrm{SO}_{4}$ en cada pozo incluyendo los dos controles. Determinar la absorbancia dentro de 30 minutos por espectrofotometría (espectrofotómetro a 450/650nm).

h) El color de los pozos del control debe tornarse amarillo, caso contrario debe ser repetido el procedimiento.

\section{Extracción del ADN}

Para la extracción de ADN se utilizó PureLink ${ }^{\circledR}$ Viral RNA/DNA Kits, (Invitrogen, CA. USA) según las especificaciones del fabricante. Se escogió este kit de extracción de ADN por estar disponible en nuestro medio al momento de la realización de las pruebas.

Recomendaciones para la extracción del ADN:

Luego de recolectada la muestra se debe proceder inmediatamente a la extracción. Si la muestra fue conservada a $4^{\circ} \mathrm{C}$ debe hacérselo hasta máximo 4 horas o las muestras congeladas a temperaturas entre $-20^{\circ} \mathrm{C}$ y $-80^{\circ} \mathrm{C}$ permiten la conservación por más tiempo. Si la muestra de suero fue congelada, debía ser centrifugada para evitar la presencia de pequeños fragmentos de hielo o de precipitados. No se debe descongelar la muestra más de una vez.

Usar el sobrenadante limpio en caso de que haya sido centrifugado, por la presencia de crioprecipitados.

\section{Extracción:}

\section{Lisis celular:}

Se colocan sucesivamente en un tubo limpio $25 \mathrm{ul}$ de proteinasa K. Luego se añaden $200 u l$ de la muestra. Se agrega $200 u l$ 
de Buffer de lisis previamente mezclado con el "Carrier de RNA", cerrar y mezclar en el vórtex por 15 segundos e incubar a $56^{\circ} \mathrm{C}$ por 25 minutos. Finalmente, colocar $250 u$ de etanol al 96\%, mezclar en el vórtex por 15 segundos e incubar la lisis por 5 minutos a temperatura ambiente (6).

\section{Proceso de purificación:}

Colocar la lisis en la columna de extracción. Centrifugar la columna a 8831,32 RPM por un minuto. Descartar lo atravesado por la columna, colocar la columna en un nuevo tubo de lavado. Lavar la columna con $500 u l$ de buffer de lavado (W5). Repetir el paso anterior una vez más con otros $500 u l$ de buffer de lavado (W5). Descartar lo atravesado por la columna y colocar la columna en un nuevo tubo de lavado. Centrifugar la columna al máximo de velocidad para filtrar cualquier residuo del buffer de lavado. Colocar la columna en un nuevo tubo de recolección (1,5ml). Colocar 10-50ul de agua estéril libre de RNasas para aislar los ácidos nucleicos. Incubar a temperatura ambiente por 1 minuto. Centrifugar al máximo de velocidad por 1 minuto. Almacenar el DNA purificado a $-80^{\circ} \mathrm{C}$ para otras aplicaciones.

\section{Amplificación del ADN}

Para la amplificación se utilizan primers dentro de la región core (3). Estos iniciadores nos determinan la pauta para poder sintetizar la región de interés con la ayuda de la polimerasa, por lo cual éstos se ubican en una posición del genoma específica en nuestro caso el primer AE-3 posición (1955-1974) 5’TTC CCT TCT GAC TTC TTT CC 3', primer AE-4 posición (2401-2381) 5’TCT GCG AGG CGA GGG AGT TCT 3'. A continuación se pueden ubicar los primers en el genoma del VHB, en la región core, antígeno "e" o en la región polimerasa.

Bajo las mismas condiciones del trabajo se estandarizaron los parámetros de PCR hasta llegar a las siguientes condiciones, con un volumen final de $25 \mathrm{ul}$, que contiene un volumen de $5 \mathrm{ul}$ de $A D N$ extraído. Platinum Taq DNA Polymerase: 1U. PCR Buffer: 10X
Primer AE-3 y primer AE-4: 0,5 pM/ul. MgCl2: 2mM. Mezcla de dNTP: 200uM. Agua estéril libre de RNasas.

Para el control de temperatura y ciclos se utilizó el termociclador Progene, con los siguientes ciclos para la amplificación: Denaturación inicial: $94^{\circ} \mathrm{C}$ por $3 \mathrm{~min}$; $30 \mathrm{Ciclos}$, cada ciclo compuesto por: Denaturación: $94^{\circ} \mathrm{C}$ por $1 \mathrm{~min}$. Alineamiento: $48^{\circ} \mathrm{C}$ por $1 \mathrm{~min}$. Extensión: $72^{\circ} \mathrm{C}$ por $2 \mathrm{~min}$.

Extensión final: $72^{\circ} \mathrm{C}$ por $7 \mathrm{~min}$.

\section{Visualización de ADN en el gel de Agarosa}

Se utilizó agarosa al 2\%, la cual se tiñó con bromuro de etidio en una concentración de 0.5 ul por cada 10ml de gel, por medio de una Electroforesis Horizontal se sometió a cargas entre 110 y 120 voltios, posteriormente se utilizó un transiluminador para visualizar el ADN teñido previamente bajo luz UV. (DyNa Light Dual Intensity UV Transilluminator)

Como controles negativos se utilizaron: suero de una persona vacunada, suero de una persona sana no vacunada y agua.

Para la comparación de las bandas obtenidas es necesario utilizar un marcador de peso molecular que en este caso es de 100 $\mathrm{pb}$, que permite evaluar un rango de fragmentos de doble cadena de entre 100-150opb.

\section{Resultados}

Se obtuvieron 35 muestras, de las cuales 26 fueron muestras de pacientes con diagnóstico de hepatitis B ya que las 26 fueron positivas para antígeno de superficie (HBsAg) 100\%, y 18 muestras fueron positivas para antígeno e (HBeAg) 69\%. (Tabla 2) Las 26 muestras positivas para $\mathrm{HBsAg}$, también resultaron positivas para la amplificación del virus HB por PCR, (vpp 1, vpn 1, sensibilidad 100\%, especificidad $100 \%$ ). 
En un paciente asintomático del grupo B (no presentaba sintomatología ni pruebas de función hepática anormales) 2,8\%, se observó la amplificación del ADN viral por PCR.

En todas las pruebas positivas la amplificación por PCR dio como resultado una banda de $447 \mathrm{pb}$, mientras que en los controles (Grupos C y D), no se obtuvo ninguna banda. (Gráfico 2)

La estandarización de la prueba de PCR se la realizó en las siguientes condiciones: concentración de Polimerasa 1U, Buffer 10X, Primers 0,5pmol/ul, cloruro de magnesio 2mM. dNTPs 200uM.

La temperatura óptima para hibridización $48^{\circ} \mathrm{C}$ por un minuto, para denaturación $94^{\circ} \mathrm{C}$ por un minuto y para extensión $72^{\circ} \mathrm{C}$ por dos minutos.

El ADN extraído y almacenado a $-80^{\circ} \mathrm{C}$ amplifica una banda de 447pb. (Gráficos 3) También se observó una banda de amplificación de $447 \mathrm{pb}$ en una de las muestras almacenadas a $-20^{\circ} \mathrm{C}$.

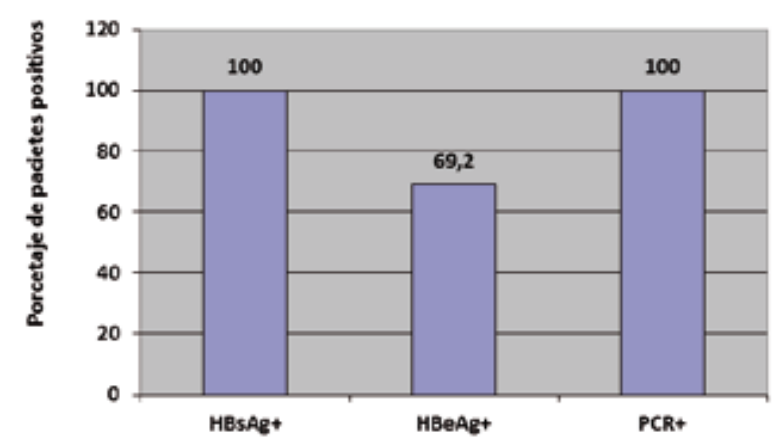

Gráfico 1. Comparación entre el porcentaje de pacientes positivos para HBsAg, HBeAg por prueba de ELISA y el porcentaje de pacientes positivos para HBV por PCR.

\begin{tabular}{|c|c|c|}
\hline $\begin{array}{l}\text { NUMERO DE } \\
\text { MUESTRA }\end{array}$ & $\begin{array}{l}\text { NOMENCLATURA DEL } \\
\text { PACIENTE }\end{array}$ & RESULTADO DE PCR \\
\hline 1 & 5B HBsAg+, HBeAg+ & Positivo \\
\hline 2 & 2A HBsAg,$+ \mathrm{HBeAg}-$ & Positivo \\
\hline 3 & 3A HBsAg+, HBeAg- & Positivo \\
\hline 4 & 4A HBsAg+, HBeAg- & Positivo \\
\hline 5 & 8A HBsAg+, HBeAg- & Positivo \\
\hline 6 & 9B HBsAg+, $\mathrm{HBeAg}+$ & Positivo \\
\hline 7 & 10B HBsAg,$+ \mathrm{HBeAg}+$ & Positivo \\
\hline 8 & 11B HBsAg+, $\mathrm{HBeAg}+$ & Positivo \\
\hline 9 & 13B HBsAg+, $\mathrm{HBeAg}+$ & Positivo \\
\hline 10 & 14B $\mathrm{HBsAg}+, \mathrm{HBeAg}+$ & Positivo \\
\hline 11 & 15B HBsAg+, $\mathrm{HBeAg}+$ & Positivo \\
\hline 12 & 16B HBsAg,$+ \mathrm{HBeAg}+$ & Positivo \\
\hline 13 & 17B HBsAg+, $\mathrm{HBeAg}+$ & Positivo \\
\hline 14 & 18B $\mathrm{HBsAg}+, \mathrm{HBeAg}+$ & Positivo \\
\hline 15 & 19B $\mathrm{HBsAg}+, \mathrm{HBeAg}+$ & Positivo \\
\hline 16 & 20B HBsAg+, $\mathrm{HBeAg}+$ & Positivo \\
\hline 17 & 21A HBsAg+, HBeAg- & Positivo \\
\hline 18 & 22A HBsAg+, HBeAg- & Positivo \\
\hline 19 & 23A HBsAg+, HBeAg- & Positivo \\
\hline 20 & 24A $\mathrm{HBsAg}+, \mathrm{HBeAg}-$ & Positivo \\
\hline 21 & 25A $\mathrm{HBsAg}+, \mathrm{HBeAg}+$ & Positivo \\
\hline 22 & 26A $\mathrm{HBsAg}+, \mathrm{HBeAg}+$ & Positivo \\
\hline 23 & $27 \mathrm{~A} \mathrm{HBsAg}+, \mathrm{HBeAg}+$ & Positivo \\
\hline 24 & 28A $\mathrm{HBsAg}+, \mathrm{HBeAg}+$ & Positivo \\
\hline 25 & 29A $\mathrm{HBsAg}+, \mathrm{HBeAg}+$ & Positivo \\
\hline 26 & 30A $\mathrm{HBsAg}+, \mathrm{HBeAg}+$ & Positivo \\
\hline
\end{tabular}

Tabla 2. Resultado de pacientes con antígenos $\mathrm{HBsAg}+$ y HBeAg+

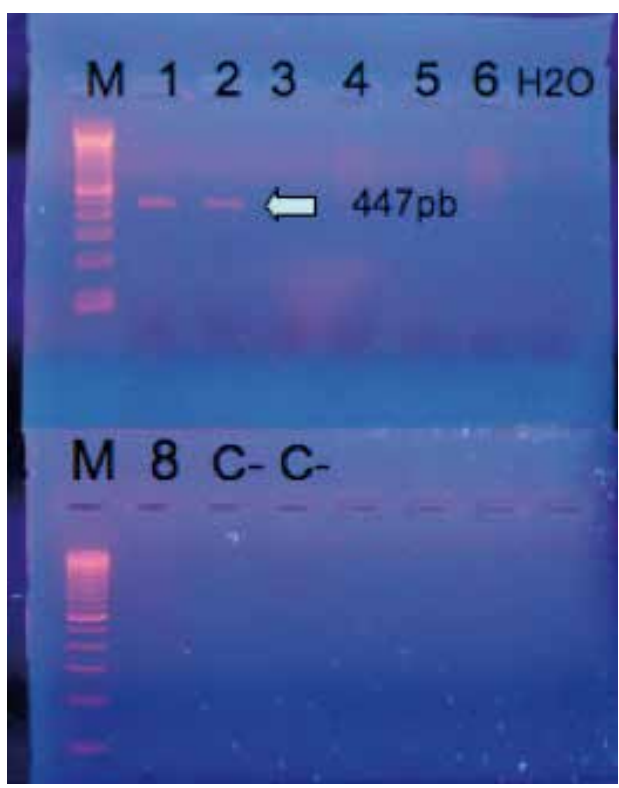

Gráfico 2. Gel de Agarosa (2\%) teñido con Bromuro de Etidio $\left(\mathrm{C}_{21} \mathrm{H}_{2} \mathrm{OBrN} 3\right)$ y visualizado bajo luz ultravioleta, $M=$ marcador molecular, 1-5= pacientes con Hepatitis B, 6=vacunado, $8=$ no vacunado, C-=Control Negativo. (Realización de la prueba inmediatamente a la toma de la muestra).

Las bandas 1 y 2 muestran la presencia de ADN viral. Emilia Espín. 


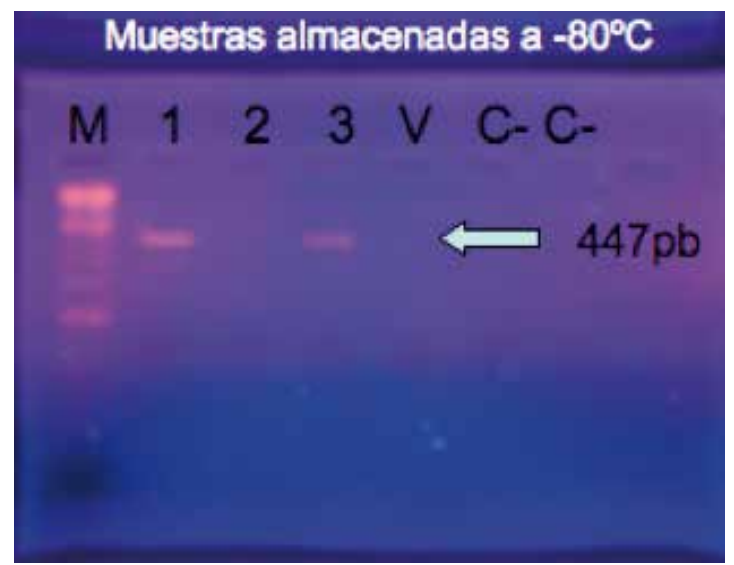

Gràfico 3. Gel de Agarosa (2\%) teñido con Bromuro de Etidio $\left(\mathrm{C}_{21} \mathrm{H}_{20 \mathrm{BrN}}\right)$ y visualizado bajo luz ultravioleta, $M=$ marcador molecular, 1-3= pacientes con Hepatitis B, V=vacunado, C-=Control Negativo. (Muestras almacenadas a $\left.-80 C^{\circ}\right)$ Emilia Espín.

\section{Conclusiones}

Cuando se dispone de las condiciones adecuadas de manejo de las muestras y control de calidad, se puede utilizar muy efectivamente la PCR como una prueba inicial de diagnóstico de los pacientes infectados por el virus hepatitis B, como sucede en el caso de selección de donantes de sangre y para trasplante de órganos, debido a que el costo de la prueba estandarizada por nuestro grupo es muy similar al costo de otras pruebas como ELISA.

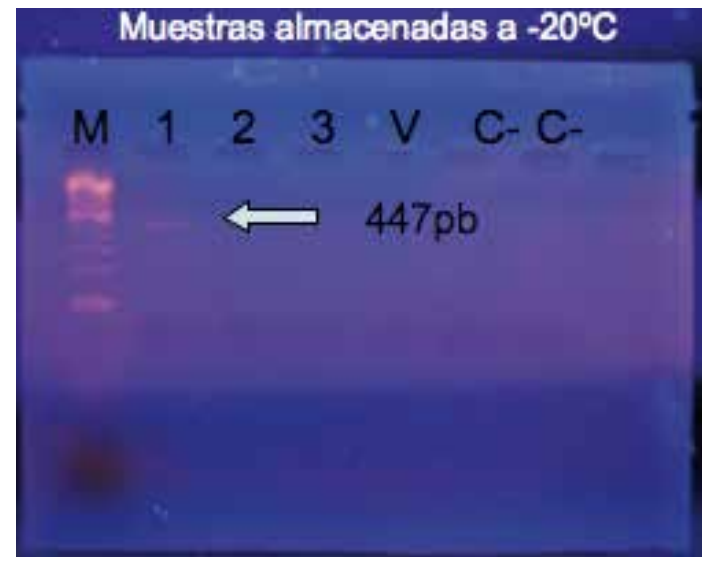

Gráfico 4. Gel de Agarosa (2\%) teñido con Bromuro de Etidio $\left(\mathrm{C}_{21} \mathrm{H}_{2} \mathrm{OBrN} 3\right)$ y visualizado bajo luz ultravioleta, $M=$ marcador molecular, 1-3= pacientes con Hepatitis B, V=vacunado, C-=Control Negativo. Un paciente amplifica la banda de $447 \mathrm{pb}$ Luego de tres días de ser almacenada a $-20^{\circ} \mathrm{C}$. Emilia Espín.

\section{Discusión}

Estos resultados presentan total concordancia con otros ensayos realizados mediante PCR por otros autores los cuales demuestran que más del 90\% de muestras positivas para HBsAg amplifican el ADN viral. (11) De igual manera se presentan resultados similares en relación a la presencia del antígeno HBeAg, el cual refleja la existencia de altos o bajos porcentajes de replicación viral. (5) Otros autores resaltan la importancia y efectividad de la prueba de PCR en diferentes manifestaciones clínicas, especialmente cuando se detectan bajos niveles de viremia en pacientes con procesos no replicativos o en pacientes con infecciones virales pasadas y en portadores asintomáticos. (7)

La PCR es una prueba sensible a bajas concentraciones de ADN; sin embargo, actualmente se prefiere utilizar el PCR cuantitativo para no solo establecer la presencia de ADN viral, sino también la carga viral presente, con el objeto de conocer la respuesta a tratamientos antivirales y/o el progreso de la enfermedad. (7)

En nuestro estudio se incluye la muestra de un paciente asintomático (Grupo B), cuyo ADN viral fue amplificado por PCR. Esto coincide con los resultados obtenidos por otros autores quienes han logrado amplificar el virus HB en un 97\% de pacientes asintomáticos que no presentan niveles alterados de transaminasas y en quienes únicamente son detectados los virus por medio de PCR u otras pruebas invasivas tales como la biopsia del hígado. (8)

En este estudio la estandarización de la Reacción en Cadena de Polimerasa (PCR) fue exitosa para la identificación del Virus de Hepatitis B en suero de todos los pacientes positivos para Antígeno de Superficie (HBsAg), por lo que puede ser utilizada como una prueba de validación.

El kit de extracción de ADN viral en columna (Invitrogen Purelink RNA/DNA) proporcionó excelentes resultados, ya que permitió extraer de manera exitosa el ADN viral. También se pudo 
comprobar que el ADN viral es muy sensible y tiende a degradarse muy rápidamente por lo que debe ser almacenado en forma óptima a temperaturas de $-80^{\circ} \mathrm{C}$, sin que se alteren los resultados de la prueba de PCR por denaturalización de la muestra.

En el caso de poseer condiciones adecuadas de manejo de las muestras y control de calidad se puede utilizar muy efectivamente la PCR como una prueba de utilización regular o de inicio para detectar los pacientes infectados por el virus hepatitis $B$, como en el caso de selección de donantes de sangre y para trasplante de órganos debido a que el costo de la prueba estandarizada es muy similar a la de ELISA.

En relación al manejo de la muestra ésta es preferible que se recolecte sin anticoagulante y que se proceda a la obtención de suero inmediatamente. Se pudo obtener mejores resultados cuando se realizó la extracción del ADN y su amplificación el mismo día de recolección de la muestra. Los resultados demuestran que las muestras procesadas inmediatamente tienen bandas mucho más claras en el gel de agarosa que aquellas en las cuales se almacenó el suero o el ADN extraído en condiciones inadecuadas; esto es, a temperatura ambiente o en refrigeración a $4^{\circ} \mathrm{C}$. (Gráfico 5)

Tampoco es recomendable descongelar la muestra más de una vez, ya que se pudo observar que en 5 muestras descongeladas varias veces, las bandas de amplificación son muy leves o no aparecen debido a la rapidez con que se degrada el ADN viral.

Debemos recalcar que por los hallazgos encontrados, esta prueba solo estaría recomendada para ser realizada a nivel hospitalario o en laboratorios clínicos que tengan la capacidad de procesar las muestras obtenidas en forma inmediata. Se pudo comprobar que la eficacia de esta técnica cualitativa de detección del virus de hepatitis B es muy adecuada y se obtienen muy buenos resultados, siempre que la muestra no se encuentre degradada. Este proceso de degradación se presenta cuando las muestras no son procesadas el mismo día, o son congeladas y descongeladas varias veces.
Esta prueba puede ser utilizada en pacientes asintomáticos en los que por sus antecedentes personales se pueda sospechar en infección por hepatitis $B$, como un método de diagnóstico de muy alta sensibilidad y especificidad que permita validar los resultados de pruebas como el análisis de HBsAg. Por los resultados obtenidos es recomendable difundir su uso con las precauciones indicadas.

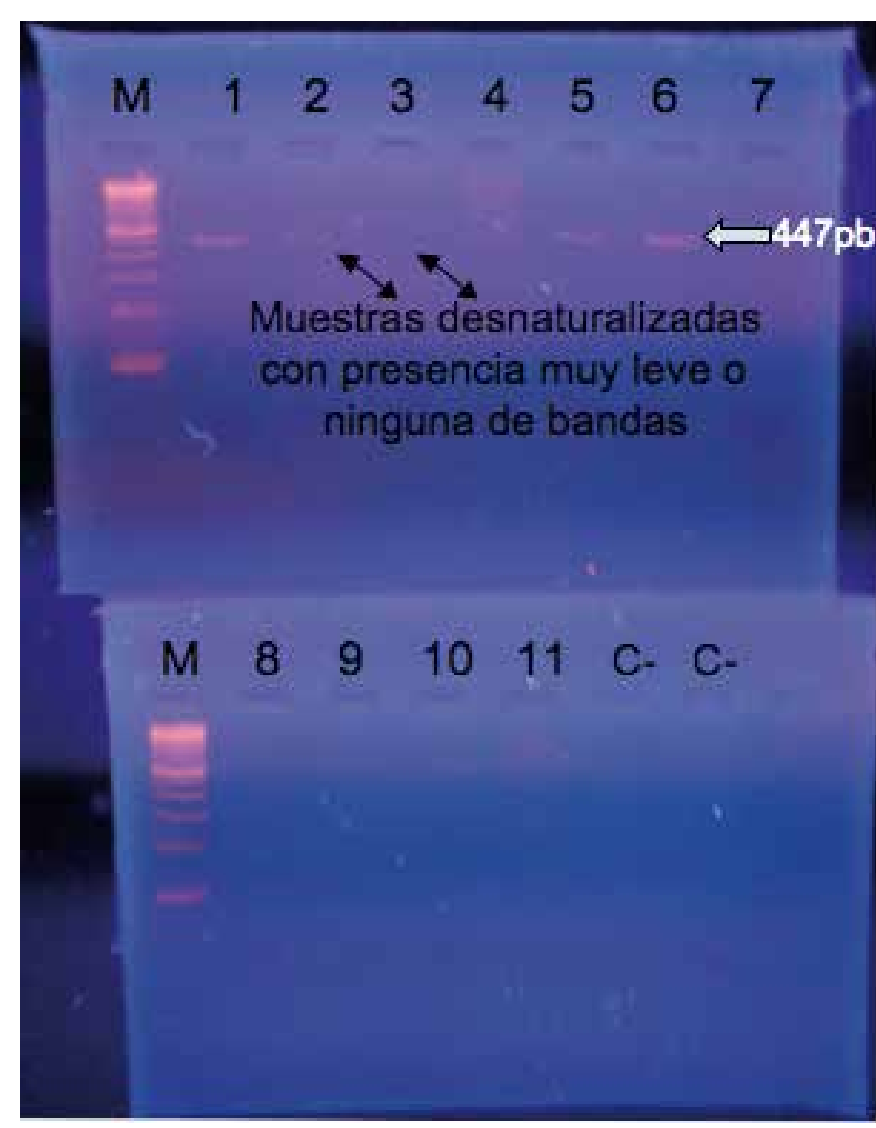

Gráfico 5. Gel de Agarosa (2\%) teñido con Bromuro de Etidio ( $\left.\mathrm{C}_{21} \mathrm{H}_{2} \mathrm{OBrN} 3\right)$ y visualizado bajo luz ultravioleta, $M=$ marcador molecular, $1-9=$ pacientes con Hepatitis B, 10=vacunado, $11=$ no vacunado, C-=Control Negativo. Muestras denaturalizadas al haber sido almacenadas a temperaturas de $4^{\circ} \mathrm{C}$. Emilia Espín. 


\section{Bibliografía}

Ministerio de Salud Pública del Ecuador. Casos de Hepatitis B en el Ecuador. http://www. msp.gov.ec/web/informacion. asp?cod=24. Acceso 12 marzo 2009.

Sanchez L. Panduro A. Genómica y Proteómica del virus de la Hepatitis B. La hepatología molecular: un enfoque multidisciplinario. vol. VII. http://www.medigraphic.com/pdfs/invsal/isg-2005/ isg051c.pdf. Acceso 29 Abril 2011.

Rodrigues C, Deshmurkh M, Jacob T, Nukala R, Menon S, Mehta A. Significance of HBV DNA by PCR over serological markers of HBV in acute and chronic patients, Department of Microbiology, Lokmanya Tilak, Municipal Medical College, Sion, Mumbai-India, vol 19 p 141-144. http://www.ijmm.org/ text.asp? 2001/19/3/141/8148. Acceso 25 Marzo 2009.

Serra Miguel A. Virus de Hepatitis B. Servicio de Hepatología, Hospital Clínico universitario de Valencia, Facultad de Medicina, Universidad de Valencia 2001. http://www.seimc.org/control/ revi_viro/VHBrev.htm. Acceso 26 Febrero 2009.

Zaaijer H, Borg F, Cuypers H, Hermes M, and Lelie P. Comparison of Methods for Detection of Hepatitis B Virus DNA. J Clin Microbiol 1994 Sep; 32(9):2088-91.

Shuichi Kaneko, Roger H. Miller, Stephen M. Feinstone, Robert H. Purcell, et al. Detection of serum hepatitis B virus DNA in patients with chronic hepatitis using the polymerase chain reaction assay. Proc Natl Acad Sci USA 1989 Jan; 86(1):312-6.

Madan K, Batra Y, Panda S, Dattagupta S, Hazari S, Kumar Jha J, and Acharya S. Role of polymerase chaín reaction and liver biopsy in the evaluation of patients with asymptomatic transaminitis: Implications in diagnostic approach. J Gastroenterol Hepatol 2004 Nov; 19(11):1291-9.

Krajden M, McNabb G., Petric M. The laboratory diagnosis of hepatitis
B virus, Can J Infect Dis Med Microbiol 2005 Mar; 16(2):65-72.

Huh HJ, Chae SL, Cha YJ. Comparison study with enzyme immunoassay and chemiluminescence immunoassay for hepatitis B virus surface antigen detection. Korean J Lab Med 2007 Oct; 27(5):355-9.

Findik D, Arslan U, Baykan M. Determination of hepatitis B virus DNA incidence, viral load, and mutations in blood donors with HBsAg and anti-HBs-negative serology and antibodies to hepatitis B core antigen. Eur J Intern Med 2007 Dec; 18(8):5715. Epub 2007 Sep 5.

Baker BL, Bisceglie AMD, Kaneko S, et al. Determination of hepatitis $B$ virus DNA in serum using the ploymerase chain reaction: clinical significance and correlation with serological and biochemical markers. Hepatology 1991 Apr; 13(4):632-6. 